\title{
Is Strip Cropping an Effective Way for Maize Biofortyfication?
}

\author{
Aleksandra Głowacka $\mathbb{D}^{1},{ }^{1}$ Bogdan Szostak $\mathbb{D}^{2}{ }^{2}$ Renata Klebaniuk, ${ }^{2}$ \\ and Anna Kiełtyka-Dadasiewicz $\mathbb{D}^{1}$ \\ ${ }^{1}$ Faculty of Agrobioengineering, University of Life Sciences in Lublin, 15 Akademicka Street, 20-950 Lublin, Poland \\ ${ }^{2}$ Institute of Animal Nutrition and Bromathology, University of Life Sciences in Lublin, 13 Akademicka Street, \\ 20-950 Lublin, Poland \\ Correspondence should be addressed to Bogdan Szostak; bogdan.szostak@up.lublin.pl
}

Received 2 May 2018; Revised 13 July 2018; Accepted 14 August 2018; Published 16 September 2018

Academic Editor: Magdalena Jastrzębska

Copyright ( $\odot 2018$ Aleksandra Głowacka et al. This is an open access article distributed under the Creative Commons Attribution License, which permits unrestricted use, distribution, and reproduction in any medium, provided the original work is properly cited.

\begin{abstract}
The aim of the study was to assess the impact of strip cropping on the content of nitrogen, phosphorus, potassium, magnesium, and calcium in maize. A field experiment was conducted during 2008-2010 in South Poland. The two cropping methods of maize were studied: sole cropping and strip cropping with common bean and spring barley. Maize was harvested in two different cycle stages: for silage in milky-wax phase and for grain in full maturity phase. Strip cropping significantly increased the accumulation of $\mathrm{Mg}$ and $\mathrm{Ca}$ by maize biomass and grain. However, the phosphorus content was higher only in maize grain. The row position in the strip influenced the macronutrients content in maize biomass and in grain. The placement adjacent to the bean resulted in higher $\mathrm{Ca}$ and $\mathrm{Mg}$ content in maize biomass and in grain. The phosphorus content in maize grain was also significantly higher in neighbouring rows with common bean strip. The least amounts of $\mathrm{P}$ and $\mathrm{N}$ were found in maize from the row adjacent to the barley strip. The results obtained indicated that strip cropping of maize with appropriate plant species, especially pulses, that is, common bean, seems to be an effective way to biofortify maize grain with Ca, especially in regions where it is the staple food. Furthermore, this may mitigate the deficiency of $\mathrm{Mg}$ and $\mathrm{Ca}$ in maize forage.
\end{abstract}

\section{Introduction}

Crop plants composition and nutritional value are very important to the health of humans and animals [1]. However, it was estimated that a considerable proportion of people worldwide suffer from deficiencies of mineral components such as $\mathrm{Fe}, \mathrm{Zn}, \mathrm{Cu}, \mathrm{Ca}$, and $\mathrm{Mg}$. Traditional strategies to deliver these nutrients have relied mainly on mineral supplementation, dietary diversification, and food fortification [2]. An alternative complimentary solution to mineral malnutrition is "biofortification." Biofortification has been defined as the process of increasing the bioavailable concentrations of essential elements in edible portions of crop plants through agronomic intervention or genetic selection [3-5]. The concept of biofortification is attractive not only for improving the growing conditions of crops but also for exploiting a plant's potential for nutrient mobilization and utilization. In addition to mineral fertilization, conventional breeding, and transgenic plants, intercropping between dicots and gramineous species would be the key to biofortification of some staple crops.

Intercropping systems involve two or more crop species or genotypes growing together and coexisting for a time. Compared with monocrops, they are reported to deliver pest control, similar yields with reduced inputs, pollution mitigation, and greater or more stable aggregate food or forage yields per unit area [5, 6]. Strip cropping can be regarded as an adaptation of the more traditional intercropping systems, but one which allows the use of modern farm machinery. The selection of plants with different developmental cycles and morphological structures enables more efficient utilization of nutrients, water, and light in strip cropping than in sole cropping. Moreover, interaction between species in the rhizosphere can affect nutrient availability and uptake [7-9]. 
Thus, the objectives of the present work were to evaluate the impact of strip cropping and time of harvest on the uptake of macronutrients by maize.

\section{Materials and Methods}

Investigations were conducted during 2008-2010 at the experimental station of the Faculty of Agricultural Sciences, University of Life Sciences in Lublin $\left(50^{\circ} 42^{\prime} \mathrm{N}, 23^{\circ} 16^{\prime} \mathrm{E}\right)$. The soil was brown soil of the group Cambisols (WRB 2007), slightly acidic ( $\mathrm{pH}$ in 1 M KCL 6.2), with organic matter content of $19 \mathrm{~g} \cdot \mathrm{kg}^{-1}$ (according to Tiurin), high content of available $\mathrm{P}\left(185 \mathrm{mg} \cdot \mathrm{kg}^{-1}\right)$ and $\mathrm{K}\left(216 \mathrm{mg} \cdot \mathrm{kg}^{-1}\right)$, and average content of $\mathrm{Mg}\left(57 \mathrm{mg} \cdot \mathrm{kg}^{-1}\right)$. The content of phosphorus and potassium in the soil was determined by the Egner-Riehm method, after extraction with calcium lactate. The magnesium content was determined using atomic absorption spectrometry after extracting from the soil with $\mathrm{CaCl}_{2}$ solution. For these extraction methods, refer to the limit numbers defining the degree of soil richness in $\mathrm{P}, \mathrm{K}$, and $\mathrm{Mg}$ used in Chemical and Agricultural Stations in Poland. The experiment employed a split-plot design with 4 replications. The two cropping methods of maize were analysed: sole cropping and strip cropping with common bean and spring barley (Figure 1). Maize was harvested in two different cycle stages: milky-wax phase for silage, $\mathrm{BBCH} 79 / 83$, and full maturity phase for grains, $\mathrm{BBCH} 99$.

In sole cropping, the size of one plot area was $26.0 \mathrm{~m}^{2}$, with 10 rows of maize per plot, and spacing between rows at $65 \mathrm{~cm}$. In strip cropping, maize was grown in adjacent strips of $3.3 \mathrm{~m}$ wide, with 5 rows of maize planted in each strip, spaced at $65 \mathrm{~cm}$. The one plot area for maize was $11.75 \mathrm{~m}^{2}$. In the successive years, maize was sown on 28 April, and 2 and 5 May. The seeding rate was 100,000 seeds per hectare. Maize for silage was harvested on 30 August 2008, 5 September 2009, and 9 September 2010. Maize for grain was harvested on 15, 11, and 13 October. Bean was grown for dry seeds and was sown in the same time as maize and was harvested on 19 August 2008, 16 August 2009, and 3 September 2010. Spring barley was sown on 12,15, and 19 April, and harvested on 2, 6, and 12 August (BBCH 89). Maize mineral fertilization was applied uniformly at the rates of $\mathrm{N} 140, \mathrm{P} 35$, and $\mathrm{K}$ $100 \mathrm{~kg} \cdot \mathrm{ha}^{-1}(\mathrm{~N}$, ammonium nitrate; $\mathrm{P}$, triple superphosphate; K, potassium salt). Phosphorus and potassium fertilizers were applied once before spring presowing treatments and nitrogen was applied in split applications (half before sowing and the remainder for top dressing in the 4-5 leaf stage, BBCH 14/15). The doses of fertilizer components were determined on the basis of soil richness and maize needs. Chemical weed regulations in maize were applied uniformly-herbicides: a.i. bromoxynil + terbuthylazine at $144 \mathrm{~g} \cdot \mathrm{ha}^{-1}+400 \mathrm{~g} \cdot \mathrm{ha}^{-1}$ at the $4-6$ leaf stage, $\mathrm{BBCH} 14 / 16$.

Weather conditions during the study are presented in Table 1. Rainfall was lowest in the second year of the experiment and was lower than the long-term average. Moreover, rainfall was unevenly distributed over the year. A severe shortage occurred in April and July, while heavy precipitation was recorded in May and June. In the first and third years of the study, rainfall was much higher and exceeded the long-term average by $56.4-61.8 \mathrm{~mm}$. Average monthly temperatures for each year were higher than the long-term average. The year 2010 was particularly warm; the temperature sum (calculated as the sum of the products of the average temperature and the number of days in the month) in the months of April-September was $3,141^{\circ} \mathrm{C}$. On the basis of Selyaninov's hydrothermal coefficient, the 2008 and 2010 growing seasons were classified as optimal, while the 2009 season was rather dry. In 2009, dry months, in particular, were April and July.

Prior to harvest in both seasons, three maize plants were collected from the middle rows of each plot. From each strip cropping plot three plants were collected from the border rows adjacent to the bean and barley strips, as well as from the middle row. The macronutrients content in maize biomass and grain was determined by the following methods: nitrogen $(\mathrm{N})$ by Kjeldahl digestion, phosphorus (P) by spectrophotometry, potassium $(\mathrm{K})$ and calcium $(\mathrm{Ca})$ by flame photometry, and magnesium $(\mathrm{Mg})$ by flame atomic absorption spectrometry (FAAS). The content of $\mathrm{P}, \mathrm{K}, \mathrm{Ca}$, and $\mathrm{Mg}$ was determined after wet mineralization of samples in a mixture of nitric and perchloric acids. The analyses were performed at the Regional Chemical and Agricultural Station in Lublin, in accordance with the standard analytical procedures. The results were converted to dry weight. The mean content of macroelements for the strip was calculated as weighted averages for the inner row and two border rows. When calculating the means, the content of the element and the yield of biomass or maize grains from individual rows were taken into account.

The results were analysed statistically by ANOVA using STATISTICA PL (Tulsa, USA). Differences between averages were determined using Tukey's test with $P<0.05$.

\section{Results and Discussion}

The yield of maize biomass and grain was the lowest in 2009 . The yield of maize biomass in the strip cropping was on average $10.7 \%$ higher than in the sole cropping (Table 2). This resulted from a significant increase in yield in the maize border row- $26.8 \%$ in the row adjacent to the common bean and $17.3 \%$ in the row next to barley.

The grain yield was also higher in strip cropping, on average for the period of research, by $14 \%$ in comparison with sole cropping. The increase in maize yield is due to its strong response to the edge effect [10] and efficient utilization of sunlight. Light interception has been observed to be highest in the border rows in strip intercropping of maize/soybean/oat [11] and maize/pea [12]. The mechanism behind that phenomenon may also be related to the corresponding below-ground root length growth and distribution advantages at later growth stages of the maize after the intercropped plants have been harvested [13].

In each year of research, as well as on average for experiment, the nitrogen and potassium content were significantly lower in the biomass of the maize grown in strip cropping than that grown in sole cropping. The 


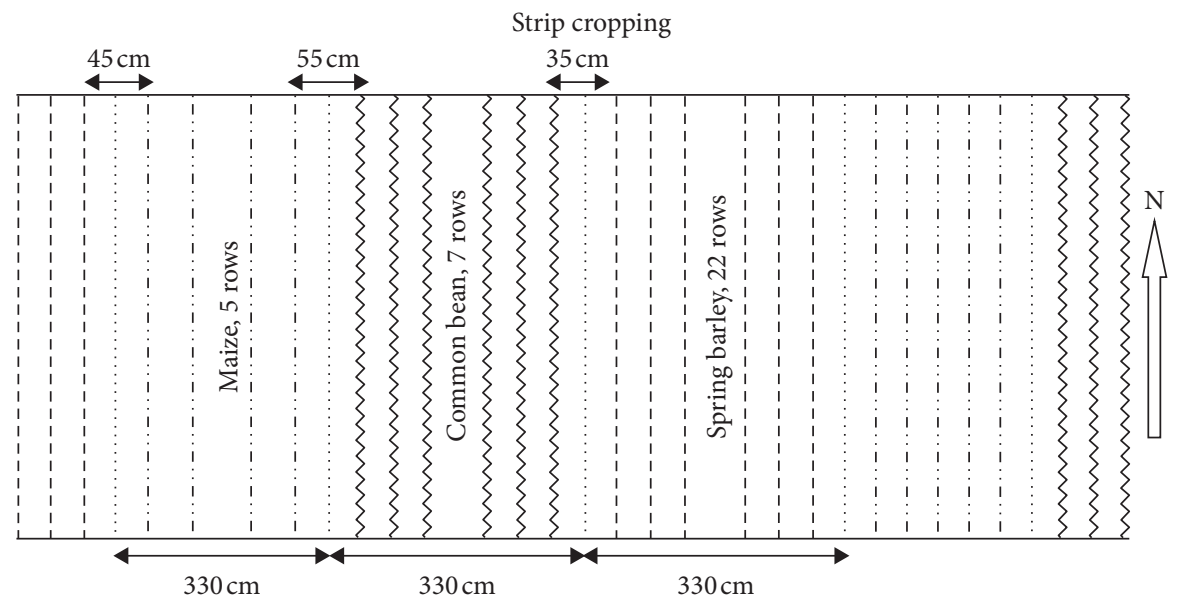

FIGURE 1: Row arrangements of maize, common bean, and spring barley in strip cropping. The row spacing of maize was $65 \mathrm{~cm}$, while that of common bean was $47 \mathrm{~cm}$, and that of spring barley was $15 \mathrm{~cm} . \mathrm{N}$, north.

TABLE 1: Rainfall and air temperature in months IV-IX as compared to the long-term means (1971-2005), according to the Meteorological Station in Zamość.

\begin{tabular}{|c|c|c|c|c|c|c|c|}
\hline Years & IV & $\mathrm{V}$ & VI & VII & VIII & IX & Sum/mean IV-IX \\
\hline \multicolumn{8}{|l|}{ Rainfall $(\mathrm{mm}), p$} \\
\hline 2008 & 71.5 & 74.8 & 48.9 & 104.6 & 69.7 & 80.4 & 449.9 \\
\hline 2009 & 15.5 & 102.6 & 124.4 & 24.2 & 48.9 & 34.5 & 350.1 \\
\hline 2010 & 30.7 & 106.7 & 62.9 & 143.5 & 86.1 & 25.4 & 455.3 \\
\hline Means for 1971-2005 & 44.1 & 65.5 & 78.9 & 98.4 & 54.3 & 52.2 & 393.5 \\
\hline \multicolumn{8}{|l|}{ Temperature $\left({ }^{\circ} \mathrm{C}\right), T$} \\
\hline 2008 & 10.7 & 15.5 & 19.4 & 20.2 & 20.6 & 19.7 & 3031 \\
\hline 2009 & 11.3 & 13.8 & 20.2 & 20.0 & 20.1 & 16.9 & 3122 \\
\hline 2010 & 11.0 & 15.1 & 18.4 & 21.5 & 20.2 & 16.6 & 3141 \\
\hline Means for $1971-2005$ & 7.9 & 14.1 & 16.8 & 18.4 & 17.8 & 12.9 & 2690 \\
\hline \multicolumn{8}{|c|}{ Selyaninov's coefficient, $k$} \\
\hline 2008 & 2.23 & 1.56 & 0.84 & 1.67 & 1.09 & 1.36 & 1.48 \\
\hline 2009 & 0.46 & 2.40 & 2.05 & 0.39 & 0.78 & 0.68 & 1.12 \\
\hline 2010 & 0.93 & 2.31 & 1.14 & 2.15 & 1.37 & 0.51 & 1.45 \\
\hline Means for 1971-2005 & 1.86 & 1.50 & 1.57 & 1.73 & 0.98 & 1.35 & 1.46 \\
\hline
\end{tabular}

$k$, Selyaninov's coefficient $\left[k=(p \times 10) / \sum t\right]$.

TABLE 2: Effect of cropping and row position in the strip on maize yield in tha $\mathrm{h}^{-1} \mathrm{DM}$.

\begin{tabular}{|c|c|c|c|c|c|c|}
\hline \multirow{3}{*}{ Phase of harvest } & \multirow{3}{*}{ Year } & \multicolumn{4}{|c|}{ Strip cropping } & \multirow{3}{*}{ Sole cropping } \\
\hline & & \multicolumn{3}{|c|}{ Row in the strip } & \multirow[t]{2}{*}{ Mean for strip } & \\
\hline & & Next to barley & Inner & Next to bean & & \\
\hline \multirow{4}{*}{ Biomass for silage } & 2008 & $20.70 \mathrm{~b}$ & $18.90 \mathrm{a}$ & $23.40 c$ & $20.60 \mathrm{~B}$ & $18.60 \mathrm{~A}$ \\
\hline & 2009 & $19.30 \mathrm{~b}$ & $17.10 \mathrm{a}$ & $20.20 \mathrm{~b}$ & $18.40 \mathrm{~B}$ & $16.60 \mathrm{~A}$ \\
\hline & 2010 & $22.10 \mathrm{~b}$ & $16.77 \mathrm{a}$ & $23.60 \mathrm{c}$ & 19.70B & $17.80 \mathrm{~A}$ \\
\hline & Mean & $20.69 b$ & $17.59 a$ & $22.40 c$ & $19.60 B$ & $17.70 \mathrm{~A}$ \\
\hline \multirow{4}{*}{ Grain } & 2008 & $6.40 \mathrm{~b}$ & $5.90 \mathrm{a}$ & $8.04 \mathrm{c}$ & $6.75 \mathrm{~B}$ & $5.80 \mathrm{~A}$ \\
\hline & 2009 & $5.40 \mathrm{a}$ & $5.10 \mathrm{a}$ & $6.72 b$ & $5.73 \mathrm{~B}$ & $5.10 \mathrm{~A}$ \\
\hline & 2010 & $5.90 \mathrm{~b}$ & $5.41 \mathrm{a}$ & $7.23 c$ & $6.15 \mathrm{~B}$ & $5.60 \mathrm{~A}$ \\
\hline & Mean & $5.90 b$ & $5.47 a$ & $7.30 c$ & $6.22 B$ & $5.50 A$ \\
\hline
\end{tabular}

Values with different letters in line differ significantly $(P=0.05)$; capital letters: cropping method; small letters: row position in the strip.

lower content of nitrogen and potassium resulted from the reduction in their content in the edge rows of the maize strip, particularly the one adjacent to barley (Table 3).
Strip cropping significantly increased the content of nitrogen in maize grain. This was particularly evident in the row adjacent to the bean strip (Table 4). Differences between the potassium content in the grain were insignificant. Barley 
TABLE 3: Effect of cropping method and row position in the strip on macronutrients content in the maize biomass harvested for silage $\left(\mathrm{g} \cdot \mathrm{kg}^{-1}\right)$.

\begin{tabular}{|c|c|c|c|c|c|c|}
\hline \multirow{3}{*}{ Nutrients } & \multirow{3}{*}{ Years } & \multicolumn{4}{|c|}{ Strip cropping } & \multirow{3}{*}{ Sole cropping } \\
\hline & & \multicolumn{3}{|c|}{ Row in the strip } & \multirow[t]{2}{*}{ Mean for strip } & \\
\hline & & Next to barley & Inner & Next to bean & & \\
\hline \multirow{4}{*}{ Nitrogen } & 2008 & $10.60 \mathrm{a}$ & $13.91 \mathrm{c}$ & $12.41 \mathrm{~b}$ & $12.26 \mathrm{~A}$ & $13.02 \mathrm{~B}$ \\
\hline & 2009 & $12.31 \mathrm{a}$ & $15.78 \mathrm{c}$ & $14.56 \mathrm{~b}$ & $14.17 \mathrm{~A}$ & $14.91 B$ \\
\hline & 2010 & $11.50 \mathrm{a}$ & $15.07 \mathrm{c}$ & $13.95 b$ & $13.38 \mathrm{~A}$ & 14.19B \\
\hline & Mean & $11.47 a$ & $14.92 c$ & $13.64 b$ & $13.27 A$ & $14.04 B$ \\
\hline \multirow{4}{*}{ Phosphorus } & 2008 & $1.95 \mathrm{a}$ & $2.35 b$ & $2.38 \mathrm{~b}$ & $2.23 \mathrm{~A}$ & $2.65 \mathrm{~B}$ \\
\hline & 2009 & $1.82 \mathrm{a}$ & $2.14 b$ & $2.26 c$ & $2.08 \mathrm{~A}$ & $2.46 \mathrm{~B}$ \\
\hline & 2010 & $2.23 \mathrm{a}$ & $2.41 b$ & $2.56 \mathrm{c}$ & $2.41 \mathrm{~A}$ & $2.75 \mathrm{~B}$ \\
\hline & Mean & $2.00 a$ & $2.30 b$ & $2.40 b$ & $2.24 A$ & $2.62 B$ \\
\hline \multirow{4}{*}{ Potassium } & 2008 & $7.52 b$ & $8.41 \mathrm{c}$ & $7.24 \mathrm{a}$ & $7.68 \mathrm{~A}$ & $9.16 \mathrm{~B}$ \\
\hline & 2009 & $8.89 a$ & $9.82 b$ & $8.93 a$ & $9.19 \mathrm{~A}$ & $10.98 \mathrm{~B}$ \\
\hline & 2010 & $8.49 \mathrm{~b}$ & $9.67 c$ & $8.13 a$ & $8.67 \mathrm{~A}$ & $10.64 \mathrm{~B}$ \\
\hline & Mean & $8.30 a$ & $9.30 b$ & $8.10 \mathrm{a}$ & $8.57 A$ & $10.26 B$ \\
\hline \multirow{4}{*}{ Magnesium } & 2008 & $0.80 \mathrm{a}$ & $1.01 \mathrm{~b}$ & $1.02 \mathrm{~b}$ & $0.94 \mathrm{~B}$ & $0.83 \mathrm{~A}$ \\
\hline & 2009 & $0.77 \mathrm{a}$ & $0.93 b$ & $0.94 b$ & $0.88 \mathrm{~B}$ & $0.74 \mathrm{~A}$ \\
\hline & 2010 & $0.83 a$ & $1.06 \mathrm{~b}$ & $1.04 \mathrm{~b}$ & $0.96 \mathrm{~B}$ & $0.86 \mathrm{~A}$ \\
\hline & Mean & $0.80 a$ & $1.00 b$ & $1.00 b$ & $0.93 B$ & $0.81 A$ \\
\hline \multirow{4}{*}{ Calcium } & 2008 & $2.41 \mathrm{a}$ & $2.81 \mathrm{~b}$ & $3.18 \mathrm{c}$ & $2.81 \mathrm{~B}$ & $2.40 \mathrm{~A}$ \\
\hline & 2009 & $2.34 \mathrm{a}$ & $2.73 b$ & $2.83 b$ & $2.64 \mathrm{~B}$ & $2.03 \mathrm{~A}$ \\
\hline & 2010 & $2.45 \mathrm{a}$ & $2.86 \mathrm{~b}$ & $3.29 c$ & $2.88 \mathrm{~A}$ & $2.35 \mathrm{~A}$ \\
\hline & Mean & $2.40 a$ & $2.80 b$ & $3.10 c$ & $2.79 B$ & $2.26 A$ \\
\hline
\end{tabular}

Values with different letters in line differ significantly $(P=0.05)$; capital letters: cropping method; small letters: row position in the strip.

TABLE 4: Effect of cropping method and row position in the strip on macronutrients content in maize grain (g. kg $\left.{ }^{-1} \mathrm{~d} . \mathrm{m}.\right)$.

\begin{tabular}{|c|c|c|c|c|c|c|}
\hline \multirow{3}{*}{ Nutrients } & \multirow{3}{*}{ Years } & \multicolumn{4}{|c|}{ Strip cropping } & \multirow{3}{*}{ Sole cropping } \\
\hline & & \multicolumn{3}{|c|}{ Row in the strip } & \multirow[t]{2}{*}{ Mean for strip } & \\
\hline & & Next to barley & Inner & Next to bean & & \\
\hline \multirow{4}{*}{ Nitrogen } & 2008 & $17.82 \mathrm{~b}$ & $17.06 \mathrm{a}$ & $18.77 \mathrm{c}$ & $17.98 \mathrm{~B}$ & $17.03 \mathrm{~A}$ \\
\hline & 2009 & $18.56 \mathrm{a}$ & $18.41 \mathrm{a}$ & $20.21 b$ & $19.76 \mathrm{~B}$ & $18.65 \mathrm{~A}$ \\
\hline & 2010 & $18.46 \mathrm{~b}$ & $18.02 \mathrm{a}$ & $19.94 c$ & $18.91 \mathrm{~B}$ & $18.26 \mathrm{~A}$ \\
\hline & Mean & $18.28 b$ & $17.83 a$ & $19.64 c$ & $18.88 B$ & $17.98 A$ \\
\hline \multirow{4}{*}{ Phosphorus } & 2008 & $3.96 \mathrm{~b}$ & $3.29 \mathrm{a}$ & $4.19 c$ & $3.86 \mathrm{~B}$ & $3.15 \mathrm{~A}$ \\
\hline & 2009 & $3.25 b$ & $2.97 \mathrm{a}$ & $3.72 \mathrm{c}$ & $3.46 \mathrm{~B}$ & $2.63 \mathrm{~A}$ \\
\hline & 2010 & $4.10 \mathrm{~b}$ & $3.76 \mathrm{a}$ & $4.36 \mathrm{c}$ & $4.10 \mathrm{~B}$ & $3.25 \mathrm{~A}$ \\
\hline & Mean & $3.77 b$ & $3.34 a$ & $4.09 c$ & $3.81 B$ & $3.01 A$ \\
\hline \multirow{4}{*}{ Potassium } & 2008 & $6.93 b$ & $6.51 \mathrm{a}$ & $7.48 \mathrm{c}$ & $7.03 \mathrm{~A}$ & $6.57 \mathrm{~A}$ \\
\hline & 2009 & $7.24 \mathrm{a}$ & $6.95 a$ & $7.72 b$ & $7.57 \mathrm{~A}$ & $7.09 \mathrm{~A}$ \\
\hline & 2010 & $7.37 \mathrm{a}$ & $7.09 a$ & $7.93 b$ & $7.51 \mathrm{~A}$ & $7.28 \mathrm{~A}$ \\
\hline & Mean & $7.18 a$ & $6.85 a$ & $7.71 b$ & $7.37 A$ & $6.98 A$ \\
\hline \multirow{4}{*}{ Magnesium } & 2008 & $1.79 \mathrm{a}$ & $1.87 \mathrm{a}$ & $2.13 b$ & $1.94 \mathrm{~B}$ & $1.52 \mathrm{~A}$ \\
\hline & 2009 & $1.93 \mathrm{a}$ & $2.05 \mathrm{a}$ & $2.27 \mathrm{~b}$ & $2.17 \mathrm{~B}$ & $1.83 \mathrm{~A}$ \\
\hline & 2010 & $1.92 \mathrm{a}$ & $1.96 \mathrm{a}$ & $2.35 b$ & $2.10 \mathrm{~B}$ & $1.75 \mathrm{~A}$ \\
\hline & Mean & $1.88 a$ & $1.96 a$ & $2.25 b$ & $2.07 B$ & $1.70 \mathrm{~A}$ \\
\hline \multirow{4}{*}{ Calcium } & 2008 & $0.84 \mathrm{a}$ & $1.03 \mathrm{~b}$ & $1.21 \mathrm{c}$ & $1.04 \mathrm{~B}$ & $0.53 \mathrm{~A}$ \\
\hline & 2009 & $0.91 \mathrm{a}$ & $1.14 \mathrm{~b}$ & $1.44 \mathrm{c}$ & $1.23 \mathrm{~B}$ & $0.69 \mathrm{~A}$ \\
\hline & 2010 & $0.95 a$ & $1.19 \mathrm{~b}$ & $1.46 \mathrm{c}$ & $1.22 \mathrm{~B}$ & $0.65 \mathrm{~A}$ \\
\hline & Mean & $0.90 a$ & $1.12 b$ & $1.37 c$ & $1.16 B$ & $0.62 A$ \\
\hline
\end{tabular}

Values with different letters in line differ significantly $(P=0.05)$; capital letters: cropping method; small letters: row position in the strip.

was sown 3 weeks earlier than maize, and may have been more competitive with the maize plants, especially in the early growth stages. Gerry and Wilson [14] reported that the initial size of the plant may influence the competitive ability of species in intercropping, although Cruse [15] believes that competition between maize and cereals in strip cropping should be minimized, as these plants have different cycles of development and their maximum demand for water and minerals occurs at different times. According to Cakmak [16], the nitrogen content in plants decreases with increased 
yield, because plants are not able to take up enough nutrients. Therefore, the changes in nitrogen and potassium content in the maize biomass found in the present study may be due to the higher maize yield in strip cropping, especially in the edge rows of the strip. This is confirmed by the higher nitrogen and potassium uptake in the rows adjacent to the beans. Ghaffarzadeh et al. [17] also argue that differences in maize yield in individual rows in the strip can affect the demand for $\mathrm{N}$ in plants; thus, additional $\mathrm{N}$ fertilizer should be applied to the edge rows, in order to realize their potential for higher yield.

In the present study, the highest nitrogen uptake by maize biomass, as well as by grain, was noted in the edge row next to bean (Figures 2 and 3). Similarly, Głowacka [18] reported the highest $\mathrm{N}$ uptake by maize in the edge row of the strip next to the lupin. This may result from the transfer of nitrogen to maize from bean, which has been observed in a number of legumes/cereal intercropping [19]. Although, according to Temperton et al. [20], the main driving force behind the facilitative interactions between $\mathrm{N}$-fixing and non- $\mathrm{N}$-fixing species is $\mathrm{N}$ sparing, i.e., reduced competition for soil $\mathrm{N}$, with $\mathrm{N}$ transfers playing a secondary role. Furthermore, the interactions between $\mathrm{N}$-fixers and non- $\mathrm{N}$-fixers are species specific and change according to the capacity of the receiver species to use $\mathrm{N}$ provided by the legume [21].

According to Inal et al. [22] improvement in soil acid phosphatase activity in rhizosphere might be responsible for increased phosphorus nutrition to plants in intercropping. In the present study, the content of phosphorus in the maize biomass in sole cropping and in strip cropping was similar (Table 3), but strip cropping significantly increased the phosphorus content in maize grain (Table 4). In part, it can be related to the fact that the intensive uptake of phosphorus by maize begins before flowering and gradually increases until ripening. So, it is in the period after the harvest of barley and beans in adjacent strips. Li et al. [23] reported that faba bean and maize intercropping facilitated phosphorus nutrition in maize. They observed that phosphorus concentration was higher in the intercropped maize than in the sole cropping plants but only during the grain filling to mature stages of maize. The improved phosphorus nutrition in maize in intercropping could have resulted from an increased uptake of $\mathrm{P}$ released during the decomposition of root residues of the faba bean. It was evident that $\mathrm{P}$ concentration and uptake in maize were increased mainly by intercropping at later growing stages after the faba bean had been harvested [23].

There is another probable explanation for this phenomenon. It was shown that faba bean, as a legume, was better nodulated when intercropped than in monoculture and may have fixed more atmospheric $\mathrm{N}$ and take up more cations than anions and release $\mathrm{H}+$ from the roots. Therefore, the increase in $\mathrm{N}$ fixation in intercropped leguminous plants may have led to increased proton excretion by legumes, and this may have contributed to the mobilization of sparingly soluble phosphate in the rhizosphere and thus improved $\mathrm{P}$ nutrition in intercropped species [22-24]. Similar facilitation in P nutrition has been found by Ae et al. [25] in sorghum/pigeon pea intercropping. Pigeon pea increased phosphorus uptake of the intercropped sorghum by exuding piscidic acid that chelates $\mathrm{Fe}^{3+}$ and subsequently releases phosphorus from $\mathrm{FePO}_{4}$.

In strip cropping, significant higher phosphorus uptake by maize biomass and by maize grain was observed in the row adjacent to bean (Figures 2 and 3). Leguminous plants have the ability to recover phosphorus from unavailable forms [26]. One mechanism is the secretion of organic acids which reduce the $\mathrm{pH}$ of the rhizosphere and release $\mathrm{P}$ from unavailable compounds. Bean mainly secretes citrates [27], while lupins and faba beans mainly secrete malate [28]. Li et al. [29] reported that chickpea contributes to higher content of phosphorus in maize/wheat intercropping. This may result from the release of carboxylates by the roots, which improve the solubility of phosphorus in the rhizosphere and increase its acquisition. According to Chen [30], the increase in phosphatase activity is accompanied by an increase in the release of phosphates from organic phosphorus compounds.

Species can facilitate each other by creating the habitat and/or increasing nutrient availability for co-occurring species [31]. Li et al. [24] showed that intercropping of wheat and chickpea increased the uptake of $\mathrm{Ca}$ and $\mathrm{Mg}$ by crop plants, and this better nutrient use was due to rhizosphere acidification. In addition, wheat produced four times more roots than chickpea and hence was more competitive to nutrient uptake. In our study, strip cropping also led to higher content of $\mathrm{Mg}$ and $\mathrm{Ca}$ in maize than sole cropping. The placement next to the bean resulted in higher content of $\mathrm{Ca}$ and $\mathrm{Mg}$ in the maize biomass and grain (Tables 3 and 4). This is consistent with the results obtained by Glowacka [18] regarding changes in the content of $\mathrm{Ca}$ and $\mathrm{Mg}$ in maize strip cropped with lupin and oats. Some plants can release greater amounts of carboxylates through their roots, which may increase utilization of Ca by coexisting plants, even from less available compounds [32]. On the other hand, legumes have a well-developed root system and may take up nutrients, that is, $\mathrm{P}, \mathrm{K}, \mathrm{Mg}$, and $\mathrm{Ca}$, in the deeper layers and move them into the soil profile, making them available to other plants [25]. Magnesium and calcium acquisition by maize intercropped with barley and common bean was significantly increased when compared with sole maize. The macronutrient accumulation by maize in the border rows, especially in the row next to bean, was significantly greater than in the inner row (Figures 2 and 3). This relationship was seen regardless of the time of maize harvest.

Maize is widely used as food for humans and as feed for animals. According to Zamora and De Regil [33] more than 200 million people rely on maize, in any of its forms, as a staple food, especially in WHO regions such as African region, region of Americas, or Southeast Asian region [34]. Maize consumption in the African WHO region ranges from 52 (in Uganda) to 328 (in Lesotho) g/person/day, whereas in the region of the Americas was the highest in Mexico $(267 \mathrm{~g} /$ person/day) $[34,35]$. Table 5 presents the estimated coverage of the demand for macroelements at various levels of maize consumption by people in different regions of the world. Taking into account the recommended daily allowance (according to WHO) for macroelements, such as $\mathrm{P}, \mathrm{Mg}$, and $\mathrm{Ca}$ and the average daily consumption of maize in 


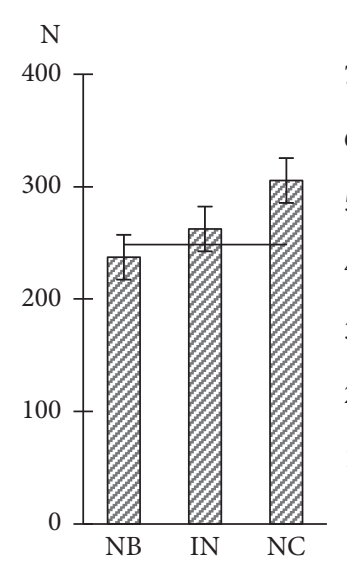

Strip cropping

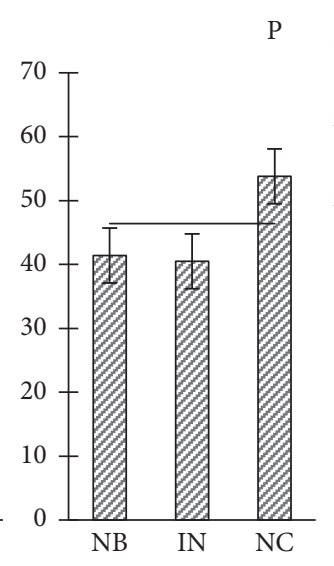

Strip cropping

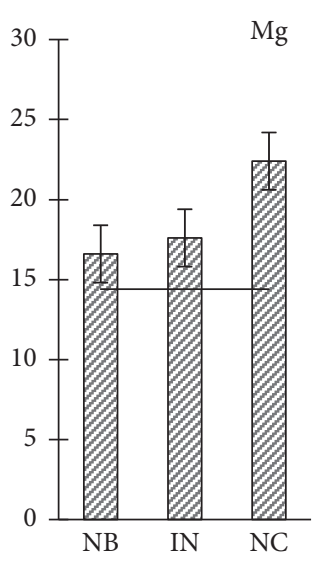

$\rightleftarrows$ Strip cropping

__ Sole cropping
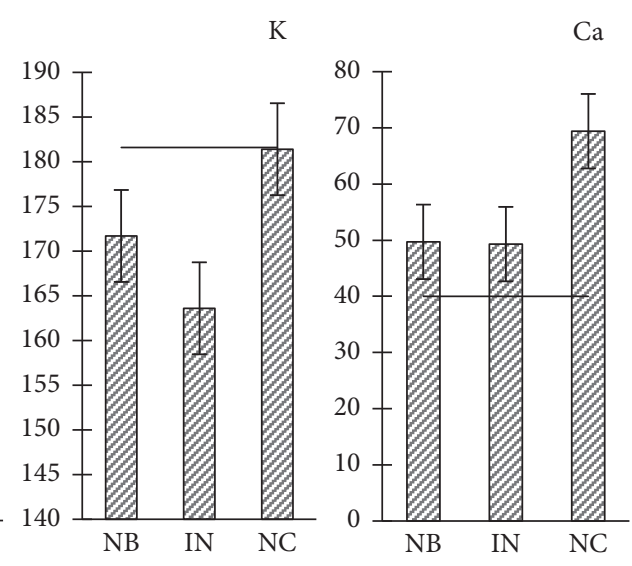

Wtrip cropping

__ Sole cropping
Strip cropping

__ Sole cropping

FIGURE 2: The influence of cropping method and row position in the strip on macronutrients uptake by maize biomass (in $\mathrm{kg} \cdot \mathrm{ha}^{-1}$ ) (mean for 2008-2010). NB, row next to barley; IN, inner row; NC, row next to common bean.

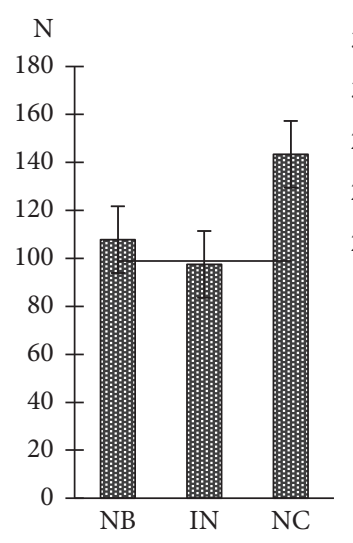

Strip cropping
- Sole cropping

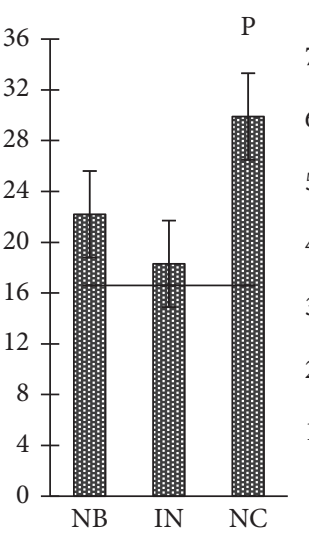

Strip cropping
- Sole cropping
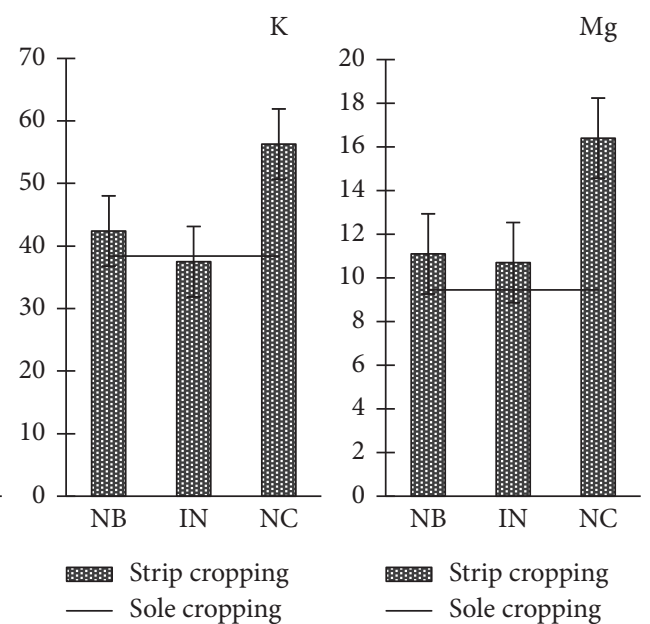

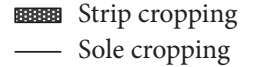

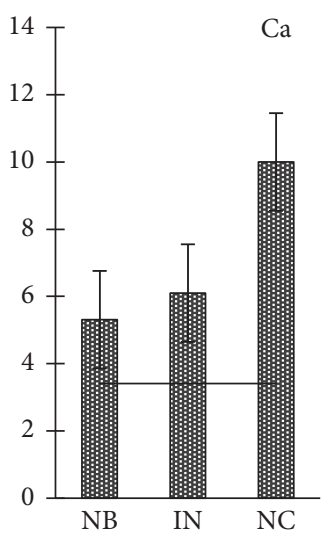

矂明明 Strip cropping

FIGURE 3: The influence of cropping method and row position in the strip on macronutrients uptake by maize grain (in kg.ha ${ }^{-1}$ ) (mean for 2008-2010). NB, row next to barley; IN, inner row; NC, row next to common bean.

TABLE 5: The amount of nutrients supplied by maize grain at different levels of human consumption (in g) and the percentage coverage of the demand for these nutrients.

\begin{tabular}{|c|c|c|c|c|c|c|c|c|c|}
\hline \multirow{4}{*}{ Element } & \multirow{4}{*}{$\operatorname{RDA}(\mathrm{g})^{1}$} & \multicolumn{8}{|c|}{ Maize consumption $\left(\text { g person }^{-1} \text { day }^{-1}\right)^{2}$} \\
\hline & & \multicolumn{4}{|c|}{52} & \multicolumn{4}{|c|}{328} \\
\hline & & \multicolumn{2}{|c|}{ Sole cropping } & \multicolumn{2}{|c|}{ Strip cropping } & \multicolumn{2}{|c|}{ Sole cropping } & \multicolumn{2}{|c|}{ Strip cropping } \\
\hline & & (g) & $(\%)$ & (g) & $(\%)$ & (g) & $(\%)$ & (g) & $(\%)$ \\
\hline $\mathrm{P}$ & $0.74-0.79$ & 0.15 & 19.5 & 0.19 & 25.7 & 0.99 & 128.6 & 1.25 & 162.3 \\
\hline $\mathrm{Mg}$ & $0.28-0.33$ & 0.09 & 31.0 & 0.10 & 34.5 & 0.56 & 193.1 & 0.68 & 234.5 \\
\hline $\mathrm{Ca}$ & $1.0-1.03$ & 0.03 & 3.00 & 0.06 & 6.00 & 0.20 & 20.0 & 0.38 & 38.0 \\
\hline
\end{tabular}

${ }^{1}$ Recommended daily allowance for adult people according to WHO [36]. ${ }^{2}$ The lowest and highest consumption of maize in countries where it is a staple food $[34,35]$.

various countries, it can be concluded that strip cropping allows for a $50 \%$ increase in the amount of $\mathrm{Ca}$ in the diet of people. This can be important in countries with a high maize consumption, of around $320 \mathrm{~g} / \mathrm{day}$, as it increases the coverage of daily Ca demand from $20 \%$ to $38 \%$ (Table 5 ). The use of maize grain from strip cropping in human nutrition may also increase the amount of $\mathrm{Mg}$ and $\mathrm{P}$ supplied with food, but to a much lesser extent.

Strip cropping increased the $\mathrm{Ca}$ and $\mathrm{Mg}$ content in the maize biomass, and thus the intake of these components by cows fed corn silage. In comparison with maize silage from sole cropping, the coverage of the daily requirement of $\mathrm{Ca}$ 
TABLE 6: The amount of nutrients supplied by maize silage at a dose of $16 \mathrm{~kg} \cdot \mathrm{d} . \mathrm{m}$. (in g) and the percentage of covering the cow's demand for these elements.

\begin{tabular}{lccccc}
\hline \multirow{2}{*}{ Element } & Daily demand $^{1}$ & \multicolumn{2}{c}{ Sole } & \multicolumn{2}{c}{ Strip } \\
& & cropping & \multicolumn{2}{c}{ cropping } \\
& & $(\mathrm{g})$ & $(\%)$ & $(\mathrm{g})$ & $(\%)$ \\
\hline $\mathrm{P}$ & 57 & 41.8 & 73.5 & 35.8 & 62.9 \\
$\mathrm{Mg}$ & 28 & 12.9 & 46.3 & 14.9 & 53.1 \\
$\mathrm{Ca}$ & 105 & 36.2 & 34.5 & 44.6 & 42.5 \\
\hline
\end{tabular}

${ }^{1}$ For a cow weighing $600 \mathrm{~kg}$ and producing approx. $20 \mathrm{~kg}$ of milk [37].

and $\mathrm{Mg}$ for cow was higher by $8 \%$ and $6.8 \%$, respectively (Table 6). Generally, maize forage is low in $\mathrm{Ca}$ and $\mathrm{Mg}$ and in order to balance the ratio, it requires the addition of mineral mixtures.

\section{Conclusion}

The results of this study confirm the impact of strip cropping on the content of macronutrients in maize. Strip cropping resulted in higher content of $\mathrm{Mg}$ and $\mathrm{Ca}$ but did not affect the $\mathrm{P}$ content in the maize biomass harvested for silage. It was also observed that the nitrogen content was slightly reduced and $\mathrm{K}$ was markedly reduced in the maize biomass harvested for silage. In maize grain, strip cropping increased the content of all macronutrients, except the content of potassium. This was due to changes in the content of elements in the maize depending on the position of the row in the strip and on the adjacent plant species. In general, the placement next to the bean strip resulted in higher content of $\mathrm{Ca}, \mathrm{Mg}$, and $\mathrm{P}$ in the maize biomass and in higher content of all investigated nutrients in maize grain. Selection of the appropriate species for strip cropping may limit shortages of some nutrients in plants. Strip cropping, especially with leguminous plants, gives the possibility of effective maize grain biofortification with $\mathrm{Ca}$. This can be used especially in regions where maize is a staple food. It is also a way to biofortify maize silage with $\mathrm{Mg}$ and $\mathrm{Ca}$ but to a much lesser extent.

\section{Data Availability}

The data used to support the findings of this study are available from the corresponding author upon request.

\section{Conflicts of Interest}

The authors declare that there are no conflicts of interest regarding the publication of this paper.

\section{Acknowledgments}

This work was supported by the Ministry of Science and Higher Education of Poland as part of statutory activities of the Faculty of Agrobioengineering (project number RKS/DS/6) and the Institute of Animal Nutrition and Bromathology, University of Life Sciences in Lublin.

\section{References}

[1] R. D. Graham, R. M. Welch, D. A. Saunders et al., "Nutritious subsistence food system," Advances in Agronomy, vol. 92, pp. 1-74, 2007.

[2] P. J. White and M. R. Broadley, "Biofortification of crops with seven mineral elements often lacking in human diets-iron, zinc, copper, calcium, magnesium, selenium and iodine," New Phytologist, vol. 182, no. 1, pp. 49-84, 2009.

[3] B. M. Waters and R. P. Sankaran, "Moving micronutrients from the soil to the seeds: genes and physiological processes from a biofortification perspective," Plant Sciences, vol. 180, no. 4, pp. 562-574, 2011.

[4] L. Ducsay, L. Ložek, M. Marček, M. Varényiová, P. Hozlár, and T. Lošák, "Possibility of selenium biofortification of winter wheat grain," Plant, Soil and Environment, vol. 62, no. 8, pp. 379-383, 2016.

[5] R. W. Brooker, A. E. Bennett, W. F. Cong et al., "Improving intercropping: a synthesis of research in agronomy, plant physiology and ecology," New Phytologist, vol. 206, no. 1, pp. 107-117, 2015.

[6] A. S. Lithourgidis, C. A. Dordas, C. A. Damalas, and D. N. Vlachostergios, "Annual intercrops: an alternative pathway for sustainable agriculture," Australian Journal of Crop Science, vol. 5, no. 4, pp. 396-410, 2011.

[7] X. Zhang, G. Huang, X. Bian, and Q. Zhao, "Effects of root interaction and nitrogen fertilization on the chlorophyll content, root activity, photosynthetic characteristics of intercropped soybean and microbial quantity in the rhizosphere," Plant, Soil and Environment, vol. 59, no. 2, pp. 80-88, 2013.

[8] A. R. Ngwira, J. B. Aune, and S. Mkwinda, "On-farm evaluation of yield and economic benefit of short term maize legume intercropping systems under conservation agriculture in Malawi," Field Crops Research, vol. 132, pp. 149-157, 2012.

[9] L. Li, D. Tilman, H. Lambers, and F. S. Zhang, "Biodiversity and overyielding: insights from below-ground facilitation of intercropping in agriculture," New Phytologist, vol. 203, no. 1, pp. 63-69, 2015.

[10] A. Głowacka, "The effects of strip cropping and weed control methods on yields of dent maize, narrow-leafed lupin and oats," International Journal of Plant Production, vol. 8, no. 4, pp. 505-529, 2014.

[11] T. W. Jurik and K. Van, "Microenvironment of corn-soybeanoat strip intercrop system," Field Crops Research, vol. 90, no. 2-3, pp. 335-349, 2005.

[12] L. Mao, L. Zhang, W. Li et al., "Yield advantage and water saving in maize/pea intercrop," Field Crops Research, vol. 138, pp. 11-20, 2012.

[13] H. Y. Xia, I. H. Zhao, J. H. Sun et al., "Dynamics of root length and distribution and shoot biomass of maize as affected by intercropping with different companion crops and phosphorus application rates," Field Crops Research, vol. 150, pp. 52-62, 2013.

[14] A. K. Gerry and S. D. Wilson, "The influence of initial size on the competitive responses of six species," Ecology, vol. 76, no. 1, pp. 272-279, 1995.

[15] R. M. Cruse, "Strip intercropping. Annual progress," Reports, Northeast Research Farm, Nashua, IA, USA, 1992.

[16] I. Cakmak, "Plant nutrition research: priorities to meet human needs for food in sustainable ways," Plant and Soil, vol. 247, no. 1, pp. 3-24, 2004.

[17] M. Ghaffarzadeh, F. Garcia-Préchac, R. M. Crusoe, and M. M. Harbur, "Fertilizer and soil nitrogen use by corn and 
border crops in a strip intercropping system," Agronomy Journal, vol. 90, no. 6, pp. 758-762, 1998.

[18] A. Głowacka, "The influence of strip cropping and adjacent plant species on the content and uptake of $\mathrm{N}, \mathrm{P}, \mathrm{K}, \mathrm{Mg}$ and $\mathrm{Ca}$ by maize (Zea mays L.)," Romanian Agricultural Research, vol. 31, pp. 219-227, 2014.

[19] C. Roscher, S. Thein, B. Schmid, and M. Scherer-Lorenzen, "Complementary nitrogen use among potentially dominant species in a biodiversity experiment varies between two years," Journal of Ecology, vol. 96, no. 3, pp. 477-488, 2008.

[20] V. M. Temperton, P. N. Mwangi, M. Scherer-Lorenzen, B. Schmid, and N. Buchmann, "Positive interactions between nitrogen-fixing legumes and four different neighbouring species in a biodiversity experiment," Oecologia, vol. 151, no. 2, pp. 190-205, 2007.

[21] A. Rutkowska and D. Pikuła, "Efficacy of ${ }^{15} \mathrm{~N}$-nitrogen in fertilization of pea mixtures with wheat, barley, and oats," Plant, Soil and Environment, vol. 62, no. 8, pp. 367-372, 2016.

[22] A. Inal, A. Gunes, F. Zhang, and I. Cakmak, "Peanut/maize intercropping induced changes in rhizosphere and nutrient concentrations in shoots," Plant Physiology and Biochemistry, vol. 45, no. 5, pp. 350-356, 2007.

[23] L. Li, F. S. Zhang, X. L. Li et al., "Interspecific facilitation of nutrient acquisition by intercropped maize and faba bean," Nutrient Cycling in Agroecosystem, vol. 65, no. 1, pp. 61-71, 2003.

[24] L. Li, C. Tang, Z. Rengel, and F. Zhang, "Calcium, magnesium and microelement uptake as affected by phosphorus sources and interspecific root interactions between wheat and chickpea," Plant and Soil, vol. 261, no. 1-2, pp. 29-37, 2004.

[25] N. Ae, J. Arihara, K. Okada, and T. Yoshihara, "Phosphorus uptake by pigeon pea and its role in cropping system of the Indian subcontinent," Science, vol. 248, no. 4954, pp. 477-480, 1990.

[26] T. R. Sinclair and V. Vadez, "The future of grain legumes in cropping systems," Crop and Pasture Sciences, vol. 63, no. 6, pp. 501-512, 2012.

[27] O. C. Nwoke, J. Diels, R. Abaidoo, G. Nziguheba, and R. Merckx, "Organic acids in the rhizosphere and root characteristics of soybean (Glycine max) and cowpea (Vigna unguiculata) in relation to phosphorus uptake in poor savanna soils," African Journal of Biotechnology, vol. 7, no. 20, pp. 3617-3624, 2008.

[28] M. Nuruzzaman, H. Lambers, M. D. A. Bollard, and E. J. Veneklaas, "Phosphorus uptake by grain legumes and subsequently grown wheat at different levels of residual phosphorus fertilizer," Australian Journal of Agricultural Research, vol. 56, no. 10, pp. 1041-1047, 2005.

[29] L. Li, C. Tang, Z. Rengel, and F. S. Zhang, "Chickpea facilitates phosphorus uptake by wheat from an organic phosphorus," Plant and Soil, vol. 248, no. 1-2, pp. 297-303, 2003.

[30] H. Chen, "Phosphatase activity and P fractions in soils of an 18-year-old Chinese fir (Cunning hamia lanceolata) plantation," Forest Ecology and Management, vol. 178, no. 3, pp. 301-310, 2003.

[31] N. Eisenhauer, "Aboveground-belowground interactions as a source of complementarity effects in biodiversity experiments," Plant and Soil, vol. 351, no. 1-2, pp. 1-22, 2012.

[32] Y. Zuo and F. Zhang, "Iron and zinc biofortification strategies in dicots plants by intercropping with gramineous species," Agronomy for Sustainable Development, vol. 29, no. 1, pp. 63-71, 2009.
[33] G. Zamora and L. M. De-Regil, "Equity in access to fortified maize flour and corn meal," Annals of the New York Academy of Sciences, vol. 1312, no. 1, pp. 40-53, 2014.

[34] P. Ranum, J. P. Pena-Rosas, and M. N. Garcia-Casal, "Global maize production, utilization, and consumption," Annals of the New York Academy of Sciences, vol. 1312, no. 1, pp. 105-112, 2014.

[35] FAO, FAOSTAT, "Food supply," 2012, http://faostat.fao.org/ site/345/default.aspx.

[36] World Health Organization (WHO)/Food and Agriculture Organization of the United Nations (FAO), Vitamin and Mineral Requirements in Human Nutrition, WHO, Geneva, Switzerland, 2nd edition, 2004, http://apps.who.int/.

[37] IZ-INRA, Feeding Standards for Cattle, Sheep and Goats. Nutritional Value of Feeds for Ruminants, IZ-INRA, Kraków, Poland, 2001. 

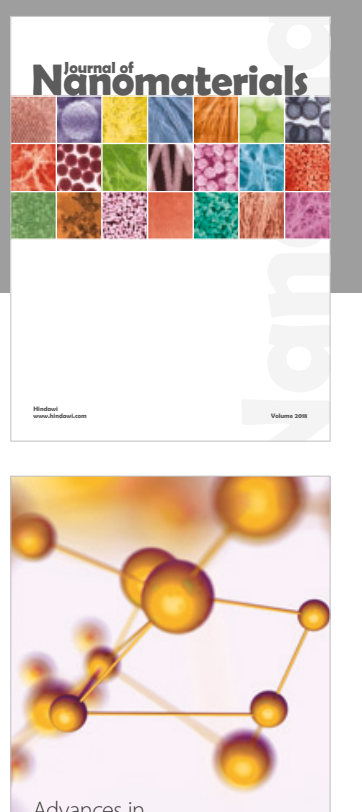

Physical Chemistry
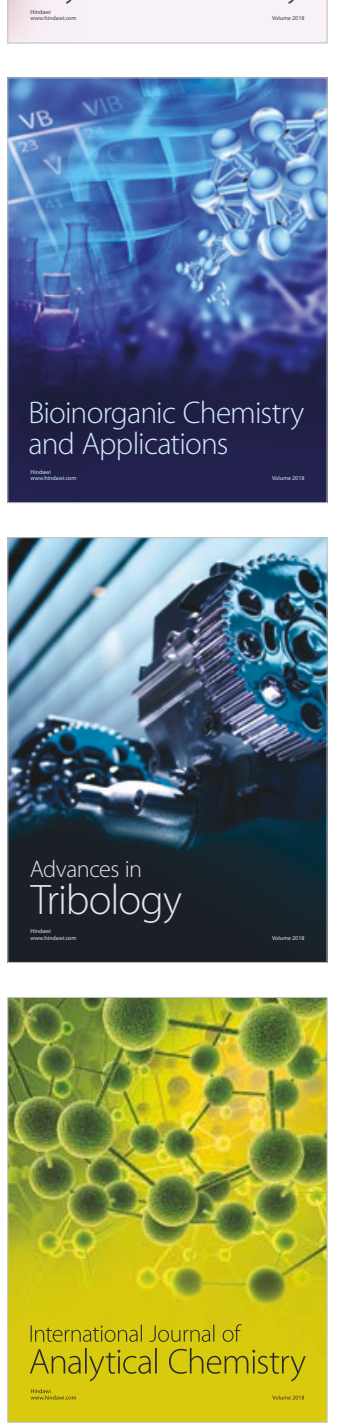

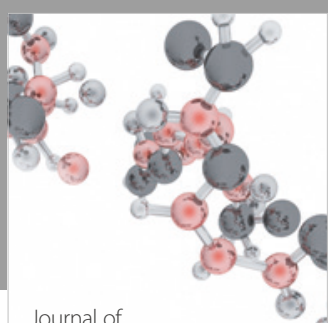

Analytical Methods

in Chemistry

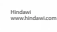

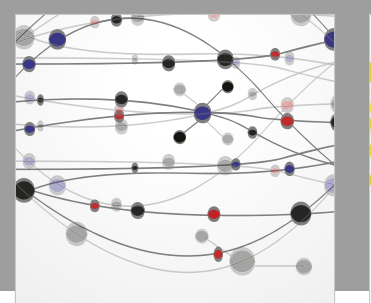

The Scientific World Journal

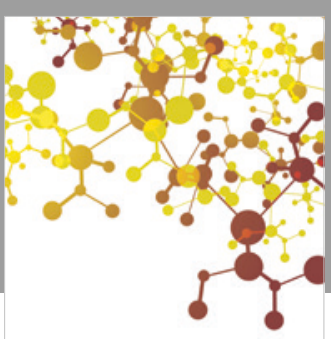

Journal of

Applied Chemistry
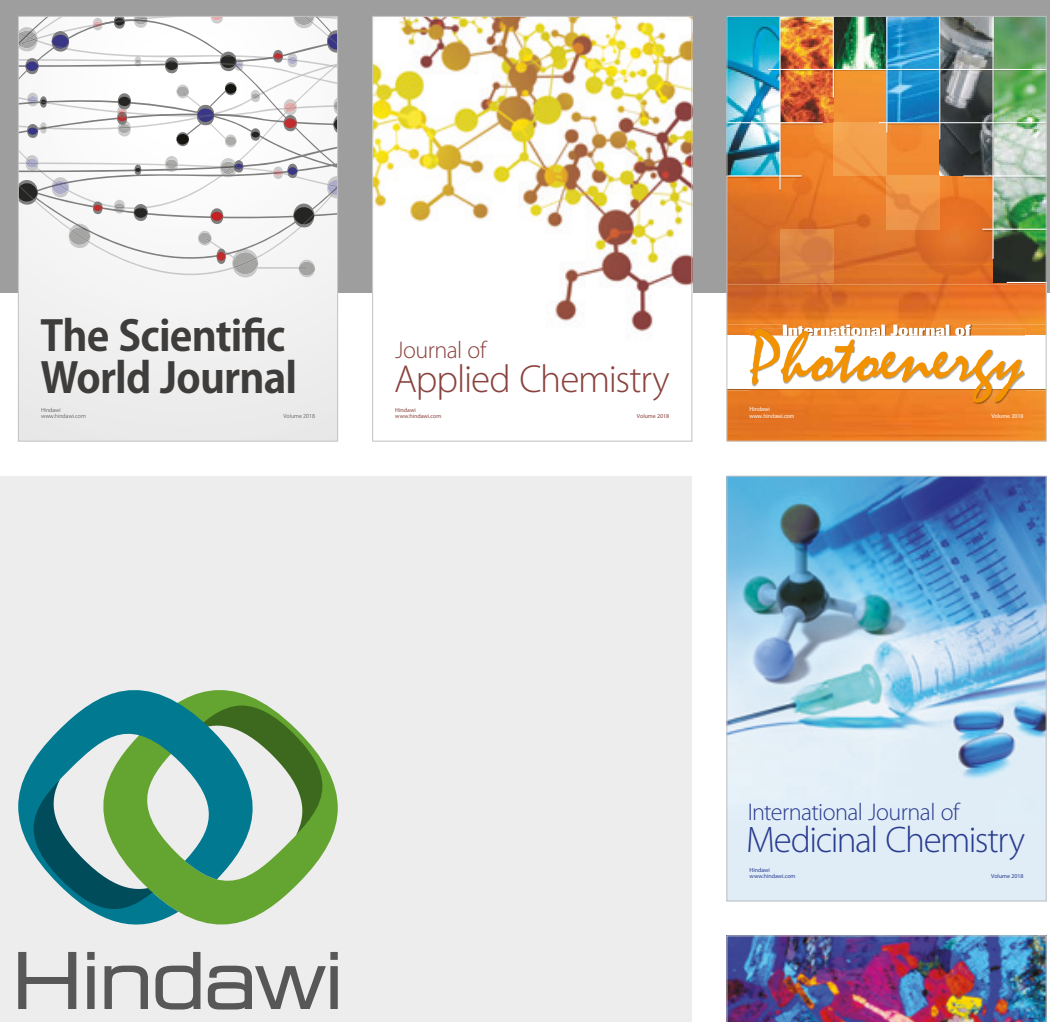

Submit your manuscripts at

www.hindawi.com
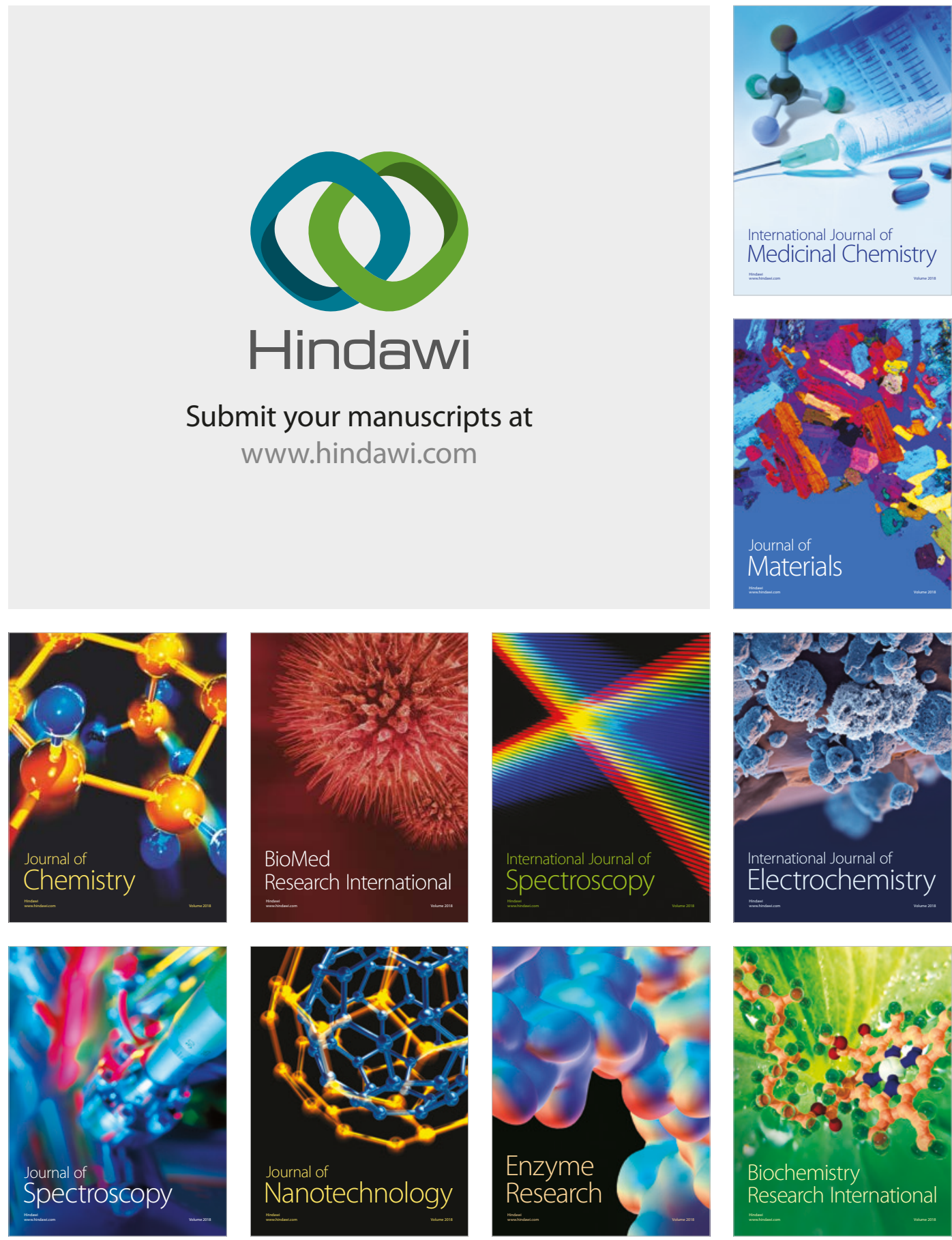
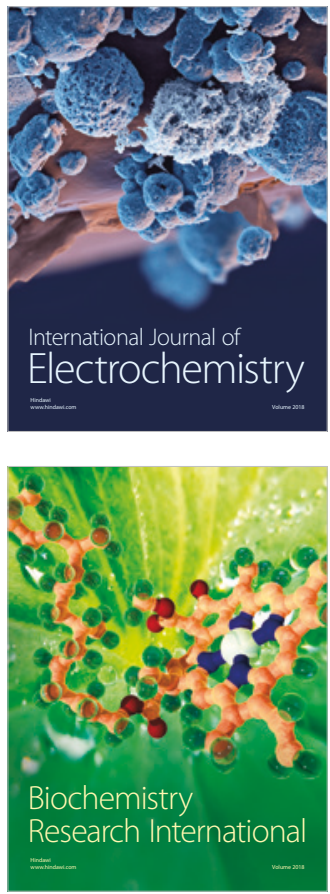